Vol. VIII No. 3, Desember 2015

P-ISSN : 1979-858X

Halaman $225-237$

\title{
PENGARUH FASILITAS DROP BOX, E-SPT DAN E-FILING DALAM PENYAMPAIAN SURAT PEMBERITAHUAN (SPT) TERHADAP KEPUASAN WAJIB PAJAK
}

\author{
Fitri Damayanti ${ }^{1}$ \\ Achmad Fauzi \\ UIN Syarif Hidayatullah Jakarta
}

\begin{abstract}
This research aims to analyze and get empirical evidence about the the influence of facilities drop box, e-SPT and e-filing submission of a letter innotice (SPT) to satisfaction of taxpayer. Respondents in this study are taxpayers in KPP Pratama Central Jakarta Regional. The number of taxpayer that were visited in this study were 75 taxpayers from 3 KPP Pratama The method of determining the sample is by using convenience sampling method, while the data processing methods used by researcher is the multiple regression analysis. The result shows the facilities drop box, e-SPT and e-filing submission of a letter innotice (SPT) partially influence to satisfaction of taxpayer.Then, facilities drop box, e-SPT and e-filing submission of a letter innotice (SPT) simultaneously and significantly influence to satisfaction of taxpayer.
\end{abstract}

Keyword: Drop Box,E-SPT, E-Filing, Satisfaction Of Taxpayer

ABSTRAK: Penelitian ini bertujuan untuk menganalisis dan mendapatkan bukti empiris tentang pengaruh fasilitas drop box, e-SPT dan e-filing dalam penyampaian Surat Pemeberitahuan (SPT) terhadap kepuasan wajib pajak. Responden dalam penelitian ini adalah para wajib pajak yang terdaftar di KPP Pratama wilayah Jakarta Pusat. Jumlah wajib pajak yang menjadi sampel penelitian ini adalah 75 responden dari 3 KPP Pratama. Metode penentuan sampel yang digunakan dalam penelitian adalah convenience sampling, sedangkan metode pengolahan data yang digunakan peneliti adalah analisi regresi berganda. Hasil penelitian ini menunjukkan bahwa penerapan fasilitas drop box, e-SPT dan e-filing dalam penyampaian Surat Pemeberitahuan (SPT) memiliki pengaruh secara parsial terhadap kepuasan wajib pajak. Kemudian, fasilitas drop box, e-SPT dan e-filing dalam penyampaian Surat Pemeberitahuan (SPT) memiliki pengaruh secara simultan dan signifikan terhadap kepuasan wajib pajak.

Kata Kunci: Drop Box, E-SPT, E-Filing Dan Kepuasan Wajib Pajak

\footnotetext{
${ }^{1}$ Draft pertama: 20 September 2015; Revisi: 25 Oktober 2015; Diterima: 16 November 2015 Penulis dapat dikontak melalui: fitri.damayanti@uinjkt.ac.i
} 


\section{PENDAHULUAN}

Pemerintah Indonesia telah berupaya keras untuk meningkatkan penerimaan dari sektor pajak, salah satu cara yang dilakukan adalah dengan melakukan Tax Reform, yaitu pembaharuan sistem perpajakan. Tax Reform dilaksanakan sejak tahun 1983, sebagaimana telah diubah dengan undang-undang Nomor 9 Tahun 1994 dan undang undang Nomor 16 Tahun 2000 tentang Ketentuan Umum dan Tata Cara Perpajakan, sistem pemungutan pajak di Indonesia berubah dari official assessment system menjadi self assessment system.

Self assessment yang dianut dalam sistem perpajakan di Indonesia menuntut wajib pajak untuk bertanggungjawab atas penghitungan, pelaporan dan pembayaran pajaknya. Bentuk pertanggungjawaban itu terlihat dari keakuratan data yang dipaparkan dalam Surat Pemberitahuan (SPT), tanpa adanya usaha untuk memanipulasi nominal dan sumber penghasilan. Pertanggungjawaban itu kemudian diwujudkan dalam bentuk kepatuhan dalam menyampaikan Surat Pemberitahuan (SPT) secara tepat waktu ke Kantor Pelayanan Pajak tempat wajib pajak tersebut terdaftar. Namun permasalahan yang dihadapi oleh Wajib Pajak di Indonesia adalah belum siapnya masyarakat untuk diterapkan self assessment system karena belum cukupnya pengetahuan perpajakan, kesadaran, dan kejujuran wajib pajak. Sebagai konsekuensinya Direktorat Jenderal Pajak berkewajiban untuk melakukan pelayanan, pengawasan, pembinaan, dan penerapan sanksi perpajakan.

Tabel 1. Target dan Realisasi Penerimaan Pajak

\begin{tabular}{|cccc|}
\hline Tahun & $\begin{array}{c}\text { Target } \\
\text { Penerimaan Pajak }\end{array}$ & $\begin{array}{c}\text { Realisasi } \\
\text { Penerimaan Pajak }\end{array}$ & $\begin{array}{c}\text { Presentase } \\
\text { Penerimaan Pajak }\end{array}$ \\
\hline 2009 & 528 triliun & 515,73 triliun & $97,61 \%$ \\
2010 & 661,4 triliun & 649,042 triliun & $98,12 \%$ \\
2011 & 878,7 triliun & 873,9 triliun & $99,3 \%$ \\
2012 & $1.016,2$ triliun & $1.021,8$ triliun & $100,5 \%$ \\
2013 & $1.139,32$ triliun & $1.099,9$ triliun & $96 \%$ \\
\hline
\end{tabular}

Sumber: Badan Kebijakan Fiskal Kementerian keuangan Republik Indonesia dan badan Pusat Statistik Republik Indonesia (Dirjen Pajak, 2013)

Dalam lima tahun terakhir penerimaan negara dari sektor pajak meningkat setiap tahunnya, meskipun belum memenuhi target yang diharapkan oleh pemerintah. Namun meningkatnya penerimaan pajak ini perlu diapresiasi serta dievaluasi sehingga kedepannya dapat memenuhi target penerimaan pajak yang telah ditentukan oleh pemerintah. Salah satu cara yang dapat dilakukan adalah meningkatkan pelayanan dalam hal pelaporan Surat Pemberitahuan (SPT), sehingga dapat meningkatkan minat para wajib pajak dalam menyampaikan Surat Pemberitahuannya.

Dalam meningkatkan pelayanan perpajakan, Direktorat Jenderal Pajak memberikan fasilitas kepada para wajib pajak dalam hal melapokan Surat Pemberitahuan (SPT). Sesuai pasal 6 ayat (2) Undang-Undang Ketentuan Umum Tata Cara Perpajakan (UU KUP) menyatakan bahwa SPT dapat disampaikan dengan cara lain. Terkait dengan peraturan Direktorat jenderal Pajak (DJP) No. KEP-47/PJ/2008 dan KEP-06/PJ/2009, telah ditetapkan cara lain tersebut, yakni secara elektronik, yang kini dikenal dengan elektronik Surat Pemberitahuan (E-SPT). E-SPT merupakan aplikasi yang dibuat oleh Direktorat Jenderal Pajak untuk digunakan oleh wajib pajak dalam melaporkan SPT nya agar lebih mudah dan tidak menghabiskan banyak kertas (peperless). Penggunaan aplikasi $e$-SPT memiliki banyak 
kemudahan untuk para Wajib Pajak karena penyampaian SPT dilakukan dengan cepat dan aman karena lampiran dalam bentuk media flaskdisk/CD/disket. Perhitungan pajak juga menjadi lebih cepat dan tepat karena menggunakan sistem komputer. Setelah mengisi $e-$ SPT, wajib pajak hanya perlu mencetak formulir induk SPT dan ditandatangani kemudian datang ke Kantor Pelayanan Pajak untuk menyerahkan formulir induk tersebut beserta file e-SPT yang telah diisi menggunakan media flaskdisk/CD/disket.

Direktorat Jenderal Pajak juga meyelenggarakan pelayanan Drop Box. Sesuai dengan Surat Edaran Direktur Jenderal Pajak Nomor SE - 15/PJ/2009 agar Kantor Pelayanan Pajak dan Kantor Penyuluhan Pelayanan dan Konsultasi Perpajakan $\left(\mathrm{KP}_{2} \mathrm{KP}\right)$ di seluruh Indonesia menyediakan Drop Box dan memasang spanduk sosialisasinya dan menempatkannya pada lokasi-lokasi yang strategis sesegera mungkin. Drop Box pertama kali dikenalkan pada tahun 2009 sebagai inovasi pelayanan dalam penerimaan SPT Tahunan. Dengan adanya fasilitas Drop Box, para wajib pajak tidak harus datang ke Kantor Pelayanan Pajak tempat dirinya terdaftar untuk menyampaikan Surat Pemberitahuan, akan tetapi wajib pajak bisa dengan mudah menyampaikan Surat Pemberitahuan tersebut melalui fasilitas Drop Box yang diselenggarakan diberbagai pusat-pusat perbelanjaan, pusat bisnis, maupun tempat lainnya dimana Drop Box ini dibuka.

Inovasi lain yang dilakukan Direktorat Jenderal Pajak yang dinilai paling efektif dan efisien adalah e-filing atau Electronic Filing System yaitu sistem pelaporan/penyampaian pajak dengan Surat Pemberitahuan (SPT) secara elektronik (e-filing) yang dilakukan melalui sistem on-line yang real time. Dalam Keputusan Direktur Jenderal Pajak tersebut dinyatakan bahwa Penyampaian Surat Pemberitahuan secara elektonik (e-SPT) dilakukan melalui Perusahaan Penyedia Jasa Aplikasi (Application Service Provider) yang ditunjuk oleh Direktur Jenderal Pajak. Untuk pengaturannya lebih lanjut maka dikeluarkanlah Peraturan Direktur Jenderal Pajak Nomor KEP- 05/PJ./2005 tanggal 12 Januari 2005 tentang Tata Cara Penyampaian Surat Pemberitahuan secara Elektronik (e-filing) melalui Perusahaan Penyedia Jasa Aplikasi (ASP).

Dengan adanya sistem ini, para Wajib Pajak lebih mudah menunaikan kewajibannya tanpa harus mengantri di Kantor-kantor Pelayanan Pajak sehingga dirasa lebih efektif dan efisien. Selain itu, pengiriman data Surat Pemberitahuan (SPT) dapat dilakukan dimana saja dan kapan saja baik di dalam maupun di luar negeri, tidak tergantung pada jam kantor dan dapat pula dilakukan di hari libur dan tanpa kehadiran Petugas Pajak (24 jam dalam 7 hari), dimana data akan dikirim langsung ke database Direktorat Jenderal Pajak dengan fasilitas internet (on-line) yang disalurkan melalui satu atau beberapa Perusahaan Penyedia Jasa Aplikasi (ASP). Jalan keluar ini membantu memangkas biaya dan waktu yang dibutuhkan wajib pajak untuk mempersiapkan, memproses dan melaporkan Surat Pemberitahuan ke Kantor Pelayanan Pajak secara benar dan tepat waktu. Dukungan kepada Kantor Pelayanan Pajak dalam hal percepatan penerimaan laporan Surat Pemberitahuan dan perampingan kegiatan administrasi, pendataan (akurasi data), distribusi dan pengarsipan Surat Pemberitahuan (SPT). Sistem e-filing ini pengoperasiannya menggunakan sistem on-line melalui internet. Di sisi wajib pajak, yang mungkin terjadi adalah kekurangmampuannya dalam melakukan sinkronisasi terhadap format data yang ada padanya dengan format data yang diinginkan oleh sistem Perusahaan Penyedia Jasa Aplikasi (ASP) dan sistem Direktorat Jenderal Pajak. Oleh karena itu, diharapkan Wajib Pajak harus berhati-hati dan harus benar-benar mengerti mengenai bagaimana penggunaan sistem ini.

Fasilitas-fasilitas yang telah dijelaskan sebelumnya, terdapat keterkaitan satu sama lain seperti penyampaian Surat Pemberitahuan melalui e-filing yang menggunakan e-SPT dalam hal penyimpanan data Wajib Pajak beserta perhitungan pajak terhutangnya. Akan tetapi e-SPT tidak serta merta disampaikan melalui e-filing. E-SPT juga bisa disampaikan dengan cara datang langsung ke Kantor Pelayanan Pajak atau dapat disampaikan melalui pelayanan Drop Box. 
Fasilitas-fasilitas yang diberikan oleh Direktorat Jenderal Pajak untuk memudahkan wajib pajak dalam menyampaikan Surat Pemberitahuan (SPT) terdapat kelebihan dan kekurangannya masing-masing, sehingga wajib pajak dapat memilih fasilitas mana yang sesuai dengan masing-masing wajib pajak.

Pajak adalah komponen penting dalam APBN, pajak menjadi andalan penerimaan terbesar pemerintah dalam melaksanakan kegiatan pembangunan, sehingga tidak heran kalau pemerintah memberikan perhatian khusus pada sektor ini untuk mengamankan penerimaan negara. Perhatian khusus yang diberikan antara lain komitmen pemerintah dalam hal ini Ditjen Pajak untuk memberikan pelayanan prima (sesuai mottonya "menjadi model pelayanan masyarakat yang menyelenggarakan sistem dan manajemen perpajakan kelas dunia yang dipercaya dan dibanggakan masyarakat").

Meningkatkan dan mengedepankan layanan ini terlihat terus dengan diberikannya fasilitas-fasiitas dalam menyampaikan Surat Pemberitahuan (SPT). Salah satunya adalah perbaikan kualitas layanan tujuannya adalah agar meningkatkan kepuasan dan kepatuhan Wajib Pajak. Upaya peningkatan kualitas layanan dapat dilakukan dengan peningkatan kualitas dan kemampuan teknis pegawai dalam bidang perpajakan, perbaikan infrastruktur, penggunaan sistem informasi dan teknologi untuk memberikan kemudahan kepada wajib pajak untuk memenuhi kewajiban perpajakannya. Kualitas pelayanan yang baik berdampak pada Kepuasan wajib pajak, sehingga akan meningkatkan kepatuhan dan kesadaran Wajib Pajak untuk membayar pajaknya tepat waktu sehingga penerimaan dapat meningkat. Peningkatan kualitas dan kuantitas pelayanan diharapkan dapat meningkatkan Kepuasan wajib pajak sebagai pelanggan.

Penelitian-penelitian sebelumnya yang menjadi dasar peneliti untuk melakukan penelitian ini yang dilakukan oleh Nugroho et. al. (2014) yang menyatakan bahwa layanan Drop Box dan e-filing berpengaruh secara simultan terhadap kepatuhan penyampaian SPT tahunan, dan penelitian yang dilakukan oleh Lingga (2013) yang menyatakan bahwa penerapan $e$-SPT berpengaruh secara signifikan terhadap kepatuhan wajib pajak.

Pemberian fasilitas-fasilitas bagi wajib pajak dalam menyampaikan Surat Pemberitahuan seperti Drop Box, e-SPT, dan e-filing berperan penting dalam sistem perpajakan di Indonesia untuk dapat dengan sukses mencapai sasaran yang diharapkan dalam menghasilkan penerimaan pajak yang optimal dan juga memberikan kepuasan terhadap wajib pajak karena membantu wajib pajak dalam melaksanakan kewajiban perpajakannya.

Tujuan dalam penelitian ini adalah untuk memberikan bukti empiris mengenai pengaruh fasilitas drop box, e-SPT dan e-filing dalam penyampaian Surat Pemberitahuan (SPT) terhadap kepuasan wajib pajak.

\section{KERANGKA TEORI DAN PENGEMBANGAN HIPOTESIS}

Surat Pemberitahuan (SPT) adalah surat yang oleh Wajib Pajak digunakan untuk melaporkan perhitungan dan/atau pembayaran pajak, objek pajak dan/atau bukan objek pajak, dan/atau harta kewajiban sesuai dengan ketentuan peraturan perundang-undangan perpajakan (Pasal 1 angka 11 UU KUP). Berdasarkan Surat Edaran Direktur Jenderal pajak Nomor 6 Tahun 2010 menyatakan Drop Box adalah tempat dimana SPT Tahunan dapat diterima. Drop Box ini sesuai namanya, berbentuk kotak berukuran cukup besar dengan logo DJP dan lubang seperti celengan tempat memasukkan SPT Tahunan. Drop Box ini ditempatkan pada tempat yang memang strategis, seperti pusat-pusat perbelanjaan dan pusat-pusat keramaian di mana saja yang nantinya akan disediakan Drop Box maupun ditaruh di kantor-kantor pajak. Menurut Pandiangan (2008) E-SPT adalah penyampaian SPT dalam bentuk digital ke KPP secara elektronik atau dengan media komputer. Salah satu 
upaya penerapan e-system dalam hal modernisasi perpajakan yang dilakukan oleh Ditjen Pajak adalah penerapan e-filing (electronic filing). Sesuai dengan Keputusan Direktur Jenderal Pajak Nomor Kep-88/ PJ/ 2004 tentang Penyampaian Surat Pemberitahuan Secara Elektronik dalam Pasal dijelaskan bahwa wajib Pajak dapat menyampaikan Surat Pemberitahuan secara elektronik melalui perusahaan penyedia jasa aplikasi (Application Service Provider) yang ditunjuk oleh Direktur Jenderal Pajak. Menurut Kotler (2000), kepuasan adalah perasaan senang atau kecewa seseorang yang muncul setelah membandingkan antara persepsi atau kesannya terhadap kinerja atau hasil suatu produk dan harapan-harapnnya. Jadi, kepuasan merupakan fungsi dari persepsi atau kesan atas kinerja dan harapan. Jika kinerja berada dibawah harapan maka pelanggan tidak puas. Jika kinerja memenuhi harapan maka pelanggan akan puas. Jika kinerja melebihi harapan maka pelanggan akan amat puas atau senang. Kunci untuk menghasikan kesetian pelanggan adalah memberikan nilai pelanggan yang tinggi.

\section{Pengaruh Fasilitas Drop Box Dalam Penyampaian Surat Pemberitahuan (SPT) Terhadap Kepuasan Wajib Pajak.}

Drop Box merupakan fasilitas yang disediakan oleh Direktorat Jendral Pajak untuk membantu masyarakat/ Wajib Pajak dalam memperoleh informasi terkait kewajiaban perpajakannya dan mempermudah masyarakat/ Wajib Pajak dalam menyampaikan SPT. Kerena sebelum ada Drop Box, dalam penyampaian Surat Pemberitahuan tahunannya, Wajib Pajak harus datang ke kantor pelayanan pajak dimana Wajib Pajak tersebut terdaftar dan setelah adanya fasilitas Drop Box ini Wajib Pajak dengan mudah dapat menyampaikan Surat Pemberitahuannya diberbagai pusat-pusat perbelanjaan, pusat bisnis, maupun tempat lainnya dimana layanan Drop Box ini dibuka. Penelitian yang dilakukan Primandari (2014), dan Nugroho et. al (2014) menyatakan bahwa Drop Box meningkatkan kepatuhan Wajib Pajak dalam menyampaikan SPT nya. Penelitian yang dilakukan oleh Sutriani (2010) juga menyatakan bahwa fasilitas Drop Box meningkatkan jumlah penyampaian SPT di KPP. Hasil dari penelitian Ula (2012) menyatakan setelah adanya fasilitas Drop Box, realisasi penerimaan pajak setiap tahun selalu diatas 96\% dari target anggaran. Oleh karena itu dapat dibuat hipotesis bahwa Drop Box berpengaruh terhadap kepuasan Wajib Pajak.

$\mathbf{H}_{\mathbf{1}}$ : Fasilitas Drop Box Dalam Penyampaian Surat Pemberitahuan (SPT) secara parsial berpengaruh terhadap Kepuasan Wajib Pajak.

\section{Pengaruh Fasilitas E-SPT Dalam Penyampaian Surat Pemberitahuan (SPT) Terhadap Kepuasan Wajib Pajak.}

E-SPT merupakan aplikasi (software) yang dibuat oleh Direktorat Jendral Pajak untuk digunakan oleh Wajib Pajak untuk kemudahan dalam penyampaian Surat Pemberitahuan (SPT). Penggunaan e-SPT dimaksudkan agar semua proses kerja dan pelayanan perpajakan berjalan dengan baik, lancar, dan akurat serta mempermudah Wajib Pajak dalam melaksanakan kewajiban perpajakannya sehingga kepatuhan pajak meningkat (Ita Salsalina Lingga, 2013). E-SPT merupakan salah satu produk kreatif dari Direktorat Jenderal Pajak. Secara keseluruhan isi program telah cukup baik, dimana pilihan-pilihan menu serta formulir SPT yang ada pada aplikasi telah sesuai dengan kebutuhan pengguna dan perbaikan atas program tersebut senantiasa dilakukan. E-SPT juga memberikan manfaat/ daya guna yang tinggi bagi penggunanya, walaupun tidak semua Informan merasakan manfaatnya. Dari pengukuran produk kreatif, penerapan e-SPT telah dipandang cukup efektif. Secara keseluruhan aktivitas penerapan e-SPT Masa PPN di KPP Pratama Singosari dipandang telah baik dan memberikan kepuasan yang tinggi baik bagi Aparatur Pajak dan sebagian besar Wajib Pajak. (Lavanda, 2013)

$\mathbf{H}_{2}$ : Fasilitas E-SPT Dalam Penyampaian Surat Pemberitahuan (SPT) secara parsial berpengaruh terhadap Kepuasan Wajib Pajak. 
Pengaruh Fasilitas E-filing Dalam Penyampaian Surat Pemberitahuan (SPT)
Terhadap Kepuasan Wajib Pajak.
E-filing adalah layanan pengisian dan penyampaian Surat Pemberitahuan Wajib Pajak secara elektronik kepada Direktorat Jenderal Pajak, dengan memanfaatkan jalur komunikasi internet. Dengan adanya sistem ini, para Wajib Pajak akan lebih mudah menunaikan kewajibannya tanpa harus mengantri di kantor pelayanan pajak sehingga dirasa lebih efektif dan efisien. Selain itu, pengiriman data Surat Pemberitahuan (SPT) dapat dilakukan dimana saja dan kapan saja baik di dalam maupun di luar negeri, tidak tergantung pada jam kantor dan dapat pula dilakukan di hari libur dan tanpa kehadiran Petugas Pajak (24 jam dalam 7 hari), dimana data akan dikirim langsung ke database Direktorat Jenderal Pajak dengan fasilitas internet (on-line) yang disalurkan melalui satu atau beberapa Perusahaan Penyedia Jasa Aplikasi (ASP). Jalan keluar ini akan membantu memangkas biaya dan waktu yang dibutuhkan Wajib Pajak untuk mempersiapkan, memproses dan melaporkan Surat Pemberitahuan ke Kantor Pelayanan Pajak secara benar dan tepat waktu. Oleh karena itu e-filing berpengaruh secara signifikan terhadap kepatuhan Wajib Pajak. (Nugroho, 2014). Kemudahan penggunaan e-filing juga berpengaruh pada Kepuasan Wajib Pajak, terdapat pengaruh positif dan sigifikan variabel Kepuasan Wajib Pajak terhadap pengguaan e-filing (Noviandini, 2012).

$\mathbf{H}_{3}$ : Fasilitas E-filing Dalam Penyampaian Surat Pemberitahuan (SPT) secara parsial berpengaruh terhadap Kepuasan Wajib Pajak.

\section{Pengaruh Fasilitas Drop Box, E-SPT dan E-filing Dalam Penyampaian Surat Pemberitahuan (SPT) Terhadap Kepuasan Wajib Pajak.}

Ketiga fasilitas yang diterbitkan oleh Direktur Jenderal Pajak untuk melayani para Wajib Pajak dalam meyampaikan Surat Pemberitahuan (SPT) yaitu Drop Box, e-SPT dan efiling mempunyai kelebihan dan kekuranggannya masing-masing. Pada intinya fasilitasfasilitas tersebut dapat saling bersinergi untuk membantu para Wajib Pajak untuk meyampaikan SPTnya secara tepat, cepat dan nyaman yang pada akhirnya akan menciptakan kepuasan bagi Wajib Pajak itu sendiri.

$\mathbf{H}_{4}$ : Fasilitas Drop Box, E-SPT dan E-filing Dalam Penyampaian Surat Pemberitahuan (SPT) secara simultan berpengaruh terhadap Kepuasan Wajib Pajak.

\section{METODE PENELITIAN}

Populasi yang digunakan dalam penelitian ini adalah keseluruhan Wajib Pajak yang berada pada Kantor Pelayanan Pajak di wilayah Jakarta Pusat. Pengambilan sampel dilakukan dengan metode convenience sampling. Pada penelitian ini, yang menjadi subyek penelitian adalah Wajib Pajak di KPP Pratama Jakarta Menteng Tiga, KPP Pratama Jakarta Kemayoran dan KPP Pratama Jakarta Sawah Besar Dua. Pengumpulan data kuesioner dilakukan dengan teknik personally administered questionnaires, yaitu kuesioner disampaikan dan dikumpulkan langsung.

\section{Definisi Operasional Variabel}

Variabel dalam penelitian ini adalah variable dependen berupa Kepuasan Wajib Pajak. Kepuasan pelanggan adalah suatu keadaan dimana keinginan, harapan dan kebutuhan pelanggan dipenuhi. Dalam hal ini pelanggan adalah Wajib Pajak. Tingkat kepuasan pelanggan terhadap pelayanan merupakan faktor penting dalam pengembanggan suatu sistem penyediaan pelayanan yang tanggap terhadap kebutuhan pelanggan. 
Variabel independen dalam penelitian ini fasilitas Drop Box $\left(\mathrm{X}_{1}\right)$ Drop Box merupakan fasilitas yang disediakan oleh Direktorat Jendral Pajak untuk membantu masyarakat/wajib pajak dalam memperoleh informasi terkait kewajiban perpajakannya dan mempermudah masyarakat/Wajib Pajak dalam menyampaikan SPT, karena setelah adanya fasilitas Drop Box ini wajib pajak dengan mudah dapat menyampaikan Surat Pemberitahuannya diberbagai pusat-pusat perbelanjaan, pusat bisnis, maupun tempat lainnya dimana layanan Drop Box ini dibuka. Fasilitas E-SPT juga dapat diartikan sebagai SPT beserta lampiranlampirannya dalam bentuk digital dan dilaporkan secara elektronik atau dengan menggunakan media penyimpanan seperti disket, CD, atau flashdisk ke KPP dimana Wajib Pajak terdaftar. Fasiltias E-filing adalah layanan pengisian dan penyampaian Surat Pemberitahuan Wajib Pajak secara elektronik kepada Direktorat Jenderal Pajak, dengan memanfaatkan jalur komunikasi internet.

\title{
Metode Analisis
}

Analisis data dilakukan dengan statistik deskriptif, uji asumsi klasik (normalitas, multikolinearitas, dan heteroskedastisitas) dan regresi linier berganda serta pengujian hipotesis (koefisien determinasi, uji $\mathrm{F}$ dan uji $\mathrm{t}$ ) dengan bantuan perangkat lunak IBM Statistical Package for Social Sciences (SPSS) versi 21.0.

Rumus persamaan regresi yang digunakan adalah sebagai berikut :

$$
\mathbf{Y}=\mathbf{a}+\boldsymbol{\beta}_{1} \mathbf{X}_{1}+\boldsymbol{\beta}_{2} \mathbf{X}_{2}+\boldsymbol{\beta}_{3} \mathbf{X}_{3}+\mathbf{e}
$$

\author{
Keterangan : \\ Y : Kepuasan Wajib Pajak \\ a : Konstanta (harga $\mathrm{Y}$, bila $\mathrm{X}=\mathrm{o}$ ) \\ b1b2 : Koefisien regresi \\ $\mathrm{X}_{1}$ : Fasilitas Drop Box \\ $\mathrm{X}_{2}$ : Fasilitas E-SPT \\ $\mathrm{X}_{3}$ : Fasilitas E-filing \\ e : Standar eror
}

\section{HASIL DAN PEMBAHASAN}

Penelitian ini dilakukan pada Wajib Pajak Orang Pribadi dan Badan yang terdaftar di Kantor Pelayanan Pajak Pratama daerah Jakarta Pusat. Secara khusus kriteria Wajib Pajak dalam penelitian ini adalah Wajib Pajak yg menggunakan fasilitas Drop Box pajak, e-SPT, dan $e$-filing dalam menyampaikan Surat Pemberitahuan (SPT).

Pengumpulan data dilakukan dengan cara menyebarkan kuesioner secara langsung kepada para responden dan penyebaran kuesioner ini dilakukan pada bulan Maret 2014 . Kuesioner disebar di tiga KPP yang berada dibawah naungan Kanwil Jakarta Pusat dengan peta distribusi seperti pada tabel 2 berikut :

Tabel 2. Data Distribusi Sampel Penelitian

\begin{tabular}{|cccc|}
\hline No. & Nama KPP & $\begin{array}{c}\text { Kuesioner } \\
\text { yang disebar }\end{array}$ & $\begin{array}{l}\text { Kuesioner yang } \\
\text { kembali }\end{array}$ \\
1 & KPP Pratama Jakarta Menteng Tiga & 20 & 20 \\
\hline
\end{tabular}




\begin{tabular}{|clcc|}
\hline 2 & $\begin{array}{l}\text { KPP Pratama Jakarta Sawah Besar } \\
\text { Dua }\end{array}$ & 20 & 20 \\
3 & $\begin{array}{l}\text { KPP Pratama Jakarta Kemayoran } \\
\text { Jumlah }\end{array}$ & 35 & 35 \\
\hline & 75 & 75 \\
\hline
\end{tabular}

Sumber : Data Primer yang diolah

Kuesioner yang disebar berjumlah 75 buah dan jumlah yang kembali sebanyak 75 buah atau $100 \%$, jumlah kuesioner yang tidak kembali berjumlah o buah atau o\%, kuesioner yang dapat diolah sebanyak 75 buah atau $100 \%$.

\section{Hasil Uji Statistik Deskriptif}

Variabel-variabel yang digunakan dalam penelitian ini meliputi fasilitas Drop Box, eSPT,e-filing, dan Kepuasan Wajib Pajak akan diuji secara statistic deskriptif seperti terlihat dalam tabel 3 berikut :

Tabel 3. Hasil Uji Statistik Deskriptif

Descriptive Statistics

\begin{tabular}{|l|r|r|r|r|r|}
\hline & & $\begin{array}{r}\text { Minimu } \\
\mathrm{m}\end{array}$ & $\begin{array}{r}\text { Maximu } \\
\mathrm{m}\end{array}$ & \multicolumn{1}{c|}{ Mean } & $\begin{array}{c}\text { Std. } \\
\text { Deviation }\end{array}$ \\
\hline TDB & 75 & 9 & 25 & 20.31 & 3.628 \\
TES & 75 & 26 & 50 & 41.23 & 5.341 \\
TEF & 75 & 26 & 55 & 41.59 & 5.477 \\
TKWP & 75 & 23 & 45 & 35.39 & 5.587 \\
Valid N & 75 & & & & \\
(listwise) & & & & \\
\hline
\end{tabular}

Sumber : Data primer yang diolah

Tabel 3 di atas menjelaskan pada variabel Drop Box jawaban minimum responden adalah sebesar 9 dan maksimum sebesar 25 dengan rata-rata total jawaban adalah 20.31 dan standar deviasi sebesar 3.628. Pada variabel e-SPT jawaban minimum responden adalah sebesar 26 dan maksimum sebesar 50 dengan rata-rata total jawaban adalah 41.23 dan standar deviasi sebesar 5.341. Pada variabel e-filing jawaban minimum responden adalah sebesar 26 dan maksimum sebesar 55 dengan rata-rata total jawaban adalah 41.59 dan standar deviasi sebesar 5.477. Sedangkan pada variabel Kepuasan Wajib Pajak jawaban minimum responden adalah sebesar 23 dan maksimum sebesar 45 dengan rata-rata total jawaban adalah 35.39 dan standar deviasi sebesar 5.587.

Berdasarkan hasil uji statistic diatas dapat disimpulkan bahwa rata-rata jawaban responden untuk variabel Drop Box, e-SPT, e-filing dan Kepuasan Wajib Pajak adalah setuju.

\section{Hasil Uji Asumsi Klasik}

Uji multikolonieritas bertujuan untuk menguji apakah model regresi ditemukan adanya korelasi antar variabel bebas (independen). Model regresi yang baik seharusnya tidak terjadi korelasi di antara variabel independen. Untuk mendeteksi adanya multikolonieritas dapat dilakukan dengan melihat nilai Tolerance dan Variance Inflation 
Factor (VIF) serta besaran korelasi antar variabel independen. Hasil uji multikolonieritas adalah sebagai berikut:

Tabel 4. Hasil Uji Multikolonieritas - Koefisien

Coefficients $^{\mathrm{a}}$

\begin{tabular}{|c|c|c|c|c|c|c|c|}
\hline \multirow[b]{2}{*}{ Model } & \multicolumn{2}{|c|}{$\begin{array}{l}\text { Unstandardized } \\
\text { Coefficients }\end{array}$} & \multirow{2}{*}{$\begin{array}{c}\begin{array}{c}\text { Standardiz } \\
\text { ed } \\
\text { Coefficient } \\
\text { s }\end{array} \\
\text { Beta }\end{array}$} & \multirow[b]{2}{*}{$\mathrm{T}$} & \multirow[b]{2}{*}{ Sig. } & \multicolumn{2}{|c|}{$\begin{array}{l}\text { Collinearity } \\
\text { Statistics }\end{array}$} \\
\hline & B & Std. Error & & & & $\begin{array}{c}\text { Toleran } \\
\text { ce }\end{array}$ & VIF \\
\hline $\begin{array}{l}\text { (Constan } \\
\text { t) }\end{array}$ & 5.176 & 4.172 & & 1.240 & .219 & & \\
\hline TDB & .416 & .192 & .270 & 2.164 & .034 & .492 & 2.032 \\
\hline TES & .288 & .143 & .276 & 2.011 & .048 & .408 & 2.452 \\
\hline TEF & .238 & .117 & .233 & 2.034 & .046 & .584 & 1.712 \\
\hline
\end{tabular}

a. Dependent Variable: TKWP

Sumber : Data primer yang diolah

Berdasarkan Tabel 4 hasil perhitungan nilai Tolerance juga menunjukkan tidak ada variabel independen yang memiliki nilai tolerance kurang dari o.10, yaitu 0.492 untuk variabel Drop Box, 0.408 untuk variabel $e$-SPT, dan 0.584 untuk variabel $e$-filing. Ini berarti tidak ada korelasi antar variabel independen yang nilainya lebih dari 95\%.

Hasil perhitungan VIF juga menunjukkan hal yang sama, yaitu tidak ada satu pun variabel independen yang memiliki nilai VIF lebih dari 10, yaitu 2.032 untuk variabel Drop $B o x, 2.452$ untuk variabel $e$-SPT, dan 1.712 untuk variabel $e$-filing. Jadi dapat disimpulkan bahwa tidak ada gejala multikolonieritas antar variabel independen dalam model regresi.

\section{Hasil Uji Hipotesis}

\section{Hasil Uji Koefisien Determinasi $\left(\mathbf{R}^{2}\right)$}

Koefisien determinasi $\left(\mathrm{R}^{2}\right)$ pada intinya mengukur seberapa jauh kemampuan model dalam menerangkan variasi variabel dependen.. Hasil uji koefisien determinasi antara Drop Box, e-SPT dan e-filing terhadap Kepuasan wajib Pajak dapat dilihat pada Tabel 5 di bawah ini:

Tabel 5. Hasil Uji Koefisien Determinasi $\left(\mathbf{R}^{2}\right)$

\begin{tabular}{|l|r|r|r|r|}
\hline & & & & \multicolumn{1}{|c|}{ Model Summary } \\
Model & $\mathrm{R}$ & R Square & Adjusted R Square & \multicolumn{1}{c|}{ Estimate } \\
\hline 1 & $.675^{\mathrm{a}}$ & .456 & .433 & 4.207 \\
\hline
\end{tabular}

a. Predictors: (Constant), TEF, TDB, TES

Sumber : Data primer yang diolah 
Tabel 5 di atas menunjukkan nilai Adjusted $R$ Square sebesar 0.433 . Hal ini menandakan bahwa variabel Drop Box, e-SPT dan e-filing hanya dapat menjelaskan 43,3\% variasi variabel Kepuasan Wajib Pajak. Sedangkan sisanya, yaitu 56,7\% (100\% - 43,3\%) dijelaskan oleh variabelvariabel lain yang tidak dijelaskan dalam penelitian seperti pelayanan Account Representative, administrasi modern, kemudahan informasi perpajakan dan lainnya.

\section{Hasil Uji Statistik t}

Uji statistik $\mathrm{t}$ pada dasarnya menunjukkan seberapa jauh pengaruh satu variabel independen secara individual dalam menerangkan variasi variabel dependen. Hasil uji regresi secara parsial (uji statistik t) ditunjukkan dalam Tabel 6 sebagai berikut:

Tabel 6. Hasil Uji Statistik t

Coefficients $^{\mathrm{a}}$

\begin{tabular}{|c|c|c|c|c|c|}
\hline \multirow[b]{2}{*}{ Model } & \multicolumn{2}{|c|}{$\begin{array}{c}\text { Unstandardized } \\
\text { Coefficients }\end{array}$} & \multirow{2}{*}{$\begin{array}{c}\text { Standardized } \\
\text { Coefficients }\end{array}$} & \multirow[b]{2}{*}{$\mathrm{t}$} & \multirow[b]{2}{*}{ Sig. } \\
\hline & B & Std. Error & & & \\
\hline $\begin{array}{ll}1 & \text { (Constant } \\
& \text { ) }\end{array}$ & 5.176 & 4.172 & & 1.240 & .219 \\
\hline TDB & .416 & .192 & .270 & 2.164 & .034 \\
\hline TES & .288 & .143 & .276 & 2.011 & .048 \\
\hline TEF & .238 & .117 & .233 & 2.034 & .046 \\
\hline
\end{tabular}

a. Dependent Variable: TKWP

Berdasarkan tabel 6, variabel Drop Box mempunyai tingkat signifikasi sebesar o,034. $\mathrm{Hal}$ ini berarti menerima $\mathrm{H}_{\mathrm{al}}$ sehingga dapat dikatakan bahwa Drop Box berpengaruh secara signifikan terhadap Kepuasan Wajib Pajak karena tingkat signifikasi yang dimiliki variabel Drop Box lebih kecil dari o,05.

Hal tersebut sejalan dengan hasil penelitian yang dilakukan oleh Chamidatul Ula (2012), Primandari (2014), Nugroho et. al. dan Desi Sutriani (2010) yang menjelaskan bahwa terdapat hubungan yang positif antara fasilitas Drop Box dalam penyampaian SPT terhadap kepuasan wajib pajak. Variabel e-SPT mempunyai tingkat signifikasi sebesar o,o48. Hal ini berarti menerima $\mathrm{H}_{\mathrm{a} 2}$ sehingga dapat dikatakan bahwa e-SPT berpengaruh secara signifikan terhadap Kepuasan Wajib Pajak karena tingkat signifikasi yang dimiliki variabel $e$-SPT lebih kecil dari o,05. Hal tersebut sejalan dengan hasil penelitian yang dilakukan oleh Lingga (2013) dan Lavanda (2013) yang menjelaskan bahwa terdapat hubungan yang positif antara fasilitas e-SPT dalam penyampaian SPT terhadap kepuasan wajib pajak. E-SPT merupakan aplikasi (software) yang dibuat oleh Direktorat Jendral Pajak untuk digunakan oleh Wajib Pajak untuk kemudahan dalam penyampaian Surat Pemberitahuan (SPT). Penggunaan eSPT dimaksudkan agar semua proses kerja dan pelayanan perpajakan berjalan dengan baik, lancar, dan akurat serta mempermudah Wajib Pajak dalam melaksanakan kewajiban perpajakannya. Tentu saja hal ini berdampak pada meningkatnya kepuasan Wajib Pajak karena e-SPT mempermudah dalam penyampaian Surat Pemberitahuan (SPT). Variabel $e-$ filing mempunyai tingkat signifikasi sebesar o,046. Hal ini berarti menerima $\mathrm{H}_{\mathrm{a} 3}$ sehingga dapat dikatakan bahwa e-filing berpengaruh secara signifikan terhadap Kepuasan Wajib Pajak karena tingkat signifikasi yang dimiliki variabel e-filing lebih kecil dari 0,05. Hal tersebut sejalan dengan hasil penelitian yang dilakukan oleh Nugroho et. al. (2014) dan Noviandini (2012) yang menjelaskan bahwa terdapat hubungan yang positif antara fasilitas 
e-filing dalam penyampaian SPT terhadap kepuasan wajib pajak. E-filing merupakan layanan pengisian dan penyampaian Surat Pemberitahuan Wajib Pajak secara elektronik kepada Direktorat Jenderal Pajak, dengan memanfaatkan jalur komunikasi internet. Dengan adanya sistem ini, para Wajib Pajak akan lebih mudah menunaikan kewajibannya tanpa harus mengantri di kantor pelayanan pajak sehingga dirasa lebih efektif dan efisien. Hal ini akan membantu memangkas biaya dan waktu yang dibutuhkan Wajib Pajak untuk mempersiapkan, memproses dan melaporkan Surat Pemberitahuan ke Kantor Pelayanan Pajak secara benar dan tepat waktu, sehingga dapat memberikan kepuasan pada Wajib Pajak dalam menyampaikan kewajiban perpajakannya.

Berdasarkan tabel 6 maka dapat diperoleh persamaan regresi sebagai berikut:

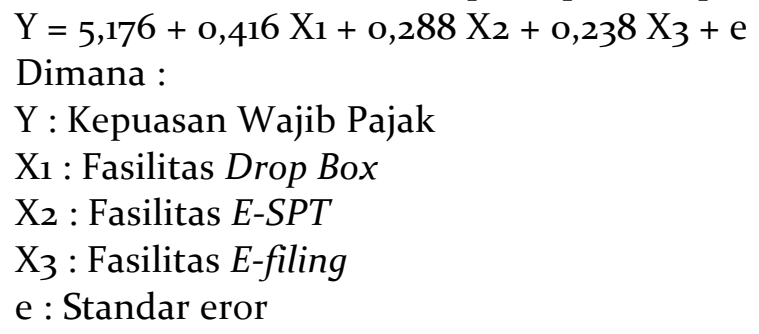

\section{Hasil Uji Statistik F}

Uji statistik F pada dasarnya menunjukkan apakah semua variabel independen yang dimasukkan ke dalam model mempunyai pengaruh secara bersama-sama terhadap variabel dependen. Hasil uji regresi secara simultan (uji statistik F) ditunjukkan dalam Tabel 7 sebagai berikut:

Tabel 7. Hasil Uji Statistik F

\begin{tabular}{|c|c|c|c|c|c|}
\hline \multicolumn{6}{|c|}{ ANOVA $^{a}$} \\
\hline Model & $\begin{array}{l}\text { Sum of } \\
\text { Squares }\end{array}$ & Df & Mean Square & $\mathrm{F}$ & Sig. \\
\hline $1 \quad$ Regression & 1053.436 & 3 & 351.145 & 19.844 & $.000^{b}$ \\
\hline Residual & 1256.351 & 71 & 17.695 & & \\
\hline Total & 2309.787 & 74 & & & \\
\hline
\end{tabular}

a. Dependent Variable: TKWP

b. Predictors: (Constant), TEF, TDB, TES

Sumber : Data primer yang diolah

Berdasarkan tabel 7, nilai F diperoleh sebesar 19,844 dengan tingkat signifikasi o,ooo. Karena tingkat signifikasi lebih kecil dari o,05, maka dapat dikatakan bahwa hipotesis $\mathrm{H}_{\mathrm{a}}$ diterima, yaitu Drop Box, e-SPT dan e-filing berpengaruh secara simultan dan signifikan terhadap Kepuasan Wajib Pajak. Hasil uji hipotesis menunjukan bahwa fasilitas Drop Box, e-SPT dan e-filing dalam penyampaian Surat Pemberitahuan (SPT) berpengaruh secara simultan dan signifikan terhadap kepuasan Wajib Pajak. Hal ini sejalan dengan penelitian yang dilakukan Nugroho et. al. (2014), Noviandini (2012), Primandari (2014), Chamidatul Ula (2012), Sutriany (2010), Lingga (2013) dan Lavanda (2013). Penelitian-penelitian tersebut meyatakan bahwa terdapat hubungan yang positif antara fasilitas Drop Box, e-SPT dan efiling dalam penyampaian Surat Pemberitahuan (SPT) terhadap kepuasan Wajib Pajak. 
Ketiga fasilitas yang diterbitkan oleh Direktur Jenderal Pajak untuk melayani para Wajib Pajak dalam meyampaikan Surat Pemberitahuan (SPT) yaitu Drop Box, e-SPT dan efiling mempunyai kelebihan dan kekuranggannya masing-masing. Pada intinya fasilitasfasilitas tersebut dapat saling bersinergi untuk membantu para Wajib Pajak untuk meyampaikan SPTnya secara tepat, cepat dan nyaman yang pada akhirnya akan menciptakan kepuasan bagi Wajib Pajak itu sendiri.

\section{SIMPULAN}

Berdasarkan data yang diperoleh dan hasil pengujian yang telah dilakukan dengan menggunakan model regresi berganda, maka dapat disimpulkan bahwa fasilitas Drop Box berpengaruh secara signifikan terhadap variabel kepuasan wajib pajak. Hasil ini sejalan dengan penelitian yang dilakukan oleh Primandari (2014), Nugroho et. al. (2014) dan Chamidatul Ula (2012) yang menyatakan bahwa terdapat hubungan positif antara fasilitas Drop Box terhadap kepuasan wajib pajak. Fasilitas e-SPT berpengaruh secara signifikan terhadap variabel kepuasan wajib pajak. Hasil ini sejalan dengan penelitian yang dilakukan oleh Lingga (2013) dan Lavanda (2013) yang menyatakan bahwa terdapat hubungan positif antara fasilitas e-SPT terhadap kepuasan wajib pajak. Fasilitas e-filing berpengaruh secara signifikan terhadap variabel kepuasan wajib pajak. Hasil ini sejalan dengan penelitian yang dilakukan oleh Nugroho et. al. (2014) dan Noviandini (2012) yang menyatakan bahwa terdapat hubungan positif antara fasilitas e-filing terhadap kepuasan wajib pajak. Hasil uji $\mathrm{F}$ menyatakan bahwa fasilitas Drop Box, e-SPT dan e-filing dalam penyampaian Surat Pemberitahuan berpengaruh secara simultan dan signifikan terhadap kepuasan Wajib Pajak. Hasil uji F secara simultan sejalan dengan penelitian yang dilakukan oleh Primandari (2014), Nugroho et. al. (2014), Chamidatul Ula (2012) Lingga (2013), Lavanda (2013) dan Noviandini (2012).

\section{PUSTAKA ACUAN}

Adriani, P.J.A .2005."Pengantar Ilmu Hukum Pajak", PT.Gramedia, Jakarta

Chen, Ching-Wen. 2010. "Impact of quality antecedents on taxpayer satisfaction with online tax-filing systems-An empirical study".

Ghozali, Imam, 2013. "Aplikasi Analisis Multivariate dengan Program IBM SPSS 21 Update PLS Regresi”, Edisi 7, BP Universitas Diponegoro, Semarang,

Ilyas, Wirawan, 2007. "Hukum Pajak", Edisi 3, Salemba Empat, Jakarta.

Indriantoro, Nur dan Bambang Supomo, 2002. "Metodologi Penelitian Bisnis". Edisi I, Penerbit BPFE, Yogyakarta.

Kotler, Philip. 200o."Manajemen Pemasaran", Pabelan Surakarta, Jakarta.

Lavanda, Casiavera. 2013. "Penerapan E-Spt Sebagai Sarana Pelaporan PPn (Studi Evaluasi Efektivitas Penerapan E-Spt Masa Ppn Pada Kantor Pelayanan Pajak (Kpp) Pratama Singosari)".

Lingga, Ita Salsalina. 2013. "Pengaruh Penerapan e-SPT Terhadap Kepatuhan Pajak: Studi Empiris Terhadap Pengusaha Kena Pajak di Wilayah KPP Pratama "X” Jawa Barat I, Jurnal Akuntansi, Vol. 5 No. 1 Mei.

Murtopo, Purno, 2011. "Perpajakan", Mitra Wacana Media, Jakarta.

Noviandini, Nurul Citra. 2012. "Pengaruh Persepsi Kebermanfaatan, Kemudahan Penggunaan, Kepuasan Wajib Pajak Terhadap Penggunaan E-Filing Bagi Wajib Pajak di Yogyakarta". Jurnal vol 1 no 1.

Nugroho, Dimas Andri Dwi. 2014. "Pengaruh Layanan Drop Box Dan E-Filing Terhadap Tingkat Kepatuhan Penyampaian Surat Pemberitahuan (Spt) Tahunan Pajak Penghasilan". 
Pandiangan, Liberti, 2007. "Modernisasi E Reformasi Pelayanan Perpajakan", PT. Elex Media Komputindo.

Primandari, Ida Ayu Putu Nomi. 2014. "Efektivitas Drop Box Sebagai Sarana Pelaporan Spt Tahunan Pada Kepatuhan Wajib Pajak Badan". E-Jurnal Akuntansi Universitas Udayana 7.2.

Saidi, Djafar, 2007."Pembaharuan Hukum Pajak”, PT. Rajagrafindo, Jakarta.

Sekaran, Uma, 2006. "Research Methods for Business: Metodologi Penelitian untuk Bisnis", Edisi 4, Salemba Empat, Jakarta.

Suandy, Erly. 2011. "Hukum Pajak", Penerbit Salemba Empat, Jakarta.

Sumarsan, Thomas, 2013. "Tax Review dan Strategi Perencanaan Pajak". Penerbit PT Indeks, Jakarta.

Sutriani, Dessy. 2010. “Tinjauan Atas Pelaksanaan Pengolahan Surat Pemberitahuan (Spt) Tahunan Pajak Penghasilan Orang Pribadi Dengan Fasilitas Drop Box Pada Kantor Pelayanan Pajak Pratama Bandung Karees".

Ula, Chamidatul. 2012. "Dropbox Pajak Sebagai Inovasi Baru Pelayanan Perpajakan Untuk Mengoptimalkan Penerimaan Pajak".

Waluyo. 2002. "Perpajakan Indonesia", Penerbit Salemba Empat, Jakarta.

www.pajak.go.id 